\title{
PENINGKATAN PENDAPATAN KELUARGA MELALUI PELATIHAN PENGOLAHAN PRODUK BERBASIS IKAN LAUT
}

\section{FAMILY INCOME GENERATING THROUGH SEA FISH PRODUCT PROCESSING TRAINING}

\author{
Oleh: \\ Barika, Ratu Eva Febriani, dan Yusnida \\ Jurusan Ekonomi Pembangunan Fakultas Ekonomi dan Bisnis Universitas Bengkulu
}

\begin{abstract}
The purpose of the community service activities are society, especially women as housewife, able to diversify its business through the business of making fish balls and fish tekwan which have high economic value. From this extension activity, women are able to increase their family income by doing business at home. Community service activity method is to conduct discussions and question and answer session conducted while delivering the training material. In addition there is a demonstration method of making meatballs and "tekwan". Berdasarkan training outcomes mother-housewife who became a trainee is able to develop products processed marine fish feed marine fish tekwan the meatballs and marine fish.
\end{abstract}

Keywords: housewife, income, sea fish products

\section{PENDAHULUAN}

Secara administratif kampung nelayan Pasar Bengkulu merupakan kelurahan yang terletak paling utara dari Kecamatan Sungai Serut yang berbatasan langsung dengan Kabupaten Bengkulu Utara. Lokasi daerah geografis Pasar Bengkulu memanjang diapit oleh Sungai Serut dan Samudera Indonesia. Berdasarkan data monografi Kampung Nelayan Kelurahan Pasar Bengkulu ini memiliki luas wilayah 7,50 Ha. Wilayah Kelurahan Pasar Bengkulu merupakan daerah beriklim panas (tropis), sebagian dari wilayahnya berbukit dan landai di tepi pantai.

Kampung nelayan Pasar Bengkulu sudah ada sejak dahulu, bahkan dari sanalah nama Bengkulu terlahir. Akan tetapi kampung nelayan tersebut kurang mendapat penanganan yang optimal dari pemerintah setempat. Kondisi kampung nelayan ini sangat kontras dengan kawasan Wisata Pantai Pasar Bengkulu dan Wisata Tapak Paderi yang letaknya bersebelahan. Pantai ini sebenarnya lebih merupakan kawasan nelayan masyarakat Pasar Bengkulu dan sekitarnya. Seharusnya kampung nelayan ini dikelola dengan baik karena mempunyai potensi yang luar biasa untuk dikembangkan menjadi objek wisata pesisir di Kota Bengkulu.

Kelurahan Pasar Bengkulu memiliki jumlah penduduk sebanyak 1.647 jiwa dengan jumlah penduduk laki-laki sebanyak 825 jiwa dan 839 jiwa perempuan. Secara rata-rata 
penduduk Kelurahan Pasar Bengkulu berpendidikan SLTA sebanyak 33,33 persen berpendidikan SMA, selanjutnya 31,73 persen berpendidikan SMP, sebanyak 5,62 persen berpendidikan di atas SMA dan sisanya belum sekolah. Berdasarkan kelompok umur, penduduk Kelurahan Pasar Bengkulu terbanyak berumur pada rentang 25 hingga 55 tahun yakni sebanyak 563 jiwa atau sebesar 33,33 persen. Rentang umur ini termasuk dalam katagori usia produktif. Dengan jumlah laki-laki sebanyak 267 jiwa dan perempuan sebanyak 296 jiwa. Lebih lengkap jumlah penduduk Kelurahan Pasar Bengkulu berdasarkan usia dapat dilihat pada Tabel 1.

Tabel 1. Jumlah Penduduk Menurut Umur

\begin{tabular}{ccccc}
\hline Usia & Laki-laki & Perempuan & Total & Persentase \\
\hline$<6$ & 85 & 97 & 182 & 10,94 \\
$7-12$ & 75 & 75 & 150 & 9,01 \\
$13-18$ & 70 & 72 & 142 & 8,53 \\
$19-24$ & 85 & 66 & 151 & 9,07 \\
$25-55$ & 267 & 296 & 563 & 33,83 \\
$56-79$ & 201 & 179 & 380 & 22,84 \\
$>80$ & 42 & 54 & 96 & 5,77 \\
\hline
\end{tabular}

Sumber: Laporan Kelurahan per Februari 2014

Ditinjau dari jenis pekerjaan yang ditekuni oleh msyarakat Kelurahan Pasar Bengkulu terdiri dari berbagai jenis pekerjaan seperti PNS, TNI/POLRI, Pedagang buruh dan lain-lain. Sebesar 45,21 persen penduduk memiliki pekerjaan sebagai buruh. Selanjutnya sebesar 27,25 persen memiliki pekerjaan sebagai nelayan. Sebesar 15,98 memiliki pekerjaan sebagai pedagang dan hanya sebesar 11,56 yang memiliki pekerjaan sebagai PNS dan TNI/Polri. Hal ini dikarenakan Kelurahan Pasar Bengkulu merupakan salah satu wilayah pesisir di Kota Bengkulu.

Kelurahan Pasar Bengkulu memiliki potensi hasil laut atau perikanan yang cukup banyak. Hasil dari perikanan di desa ini dijadikan produk olahan seperti ikan asin. Kegiatan ini umumnya dilakukan oleh ibu-ibu rumah tangga dibantu oleh pria dalam hal penangkapan ikan. Hasil penjualan sebagian besar digunakan dalam pemenuhan kebutuhan sehari-hari. Sehingga jelas terlihat bahwa kaum wanita memiliki peluang yang relatif lebih besar dalam pengelolaan keuangan rumah tangganya.

Kaum perempuan memiliki peluang untuk menambah penghasilan keluarga baik dari usaha membantu suami dalam pengolahan produksi ikan maupun berdagang di kawasan wisata pantai jakat. Akan tetapi terkadang terdapat hambatan dalam memproduksi. Seperti disaat cuaca yang tidak bagus, maka nelayan tidak melaut dan hasil tangkap sedikit dan jumlah wisatawan pun sedikit. Oleh karena itu sudah selayaknya kaum perempuan mencari alternatif usaha lain dalam menambah penghasilan keluarga. Dengan melakukan usaha yang tetap dilakukan di rumah (home industry).

Secara prosentase jumlah perempuan di Kelurahan Pasar Bengkulu lebih banyak dibandingkan jumlah laki-laki. Berdasarkan kelompok umur, jumlah penduduk perempuan yang dalam usia produktif sebanyak 296 jiwa. Hampir sebagian besar merupakan kelompok ibu-ibu rumah tangga. Kaum perempuan memiliki peluang untuk menambah 
penghasilan keluarga baik dari usaha membantu suami dalam pengolahan produksi ikan maupun berdagang di kawasan wisata Pantai Zakat.

Berdasarkan analisis situasi dan analisis data potensi Kelurahan Pasar Bengkulu serta hasil survey awal pada aparatur pemerintahan yang ada di Kelurahan Pasar Bengkulu maka dapat disimpulkan bahwa masyarakat Kelurahan Pasar Bengkulu terutama kaum ibu rumah tangga layak mendapatkan penyuluhan tentang teknik pengolahan hasil laut atau hasil tangkapan.

Konsep pendapatan menurut ilmu ekonomi dikemukakan oleh Wild dan Robert (2003: 311), "economic income is typically measured as cash flow plus the change in the fair value of net assets. Under this definition, income includes both realized (cash flow) and unrealized (holding gain or loss) components". Menurut Wild, pendapatan secara khusus diukur sebagai aliran kas ditambah perubahan dalam nilai bersih aktiva. Wild memasukkan pendapatan yang dapat direalisasi sebagai komponen pendapatan. Sedangkan Harahap (2002: 58) mendefinisikan pendapatan sebagai "kenaikan gross di dalam asset dan penurunan gross dalam kewajiban yang dinilai berdasarkan prinsip akuntansi yang berasal dari kegiatan mencari laba".

Pengertian pendapatan dikemukakan oleh Dyckman, et al (2002: 234) bahwa pendapatan adalah "arus masuk atau peningkatan lainnya atas aktiva sebuah entitas atau penyelesaian kewajiban (atau kombinasi dari keduanya) selama satu periode dari pengiriman atau produksi barang, penyediaan jasa, atau aktivitas lain yang merupakan operasi utama atau sentral entitas yang sedang berlangsung”.

Hasil perikanan di Indonesia pada umumnya disajikan dalam dua bentuk, yaitu segar dan olahan; yang meliputi olahan tradisional dan olahan modern. Menurut Penelitian yang dilakukan oleh Erizal (1991) adalah menyatakan bahwa kegiatan pengolahan ikan secara tradisional, khususnya kegiatan pengeringan dan penggaraman ikan, merupakan bentuk pengolahan yang banyak dilakukan nelayan di Sumatera Utara. Sebesar 70,38\% dari bentuk pengolahan ikan dilakukan dengan cara pengeringan dan penggaraman. Secara umum kegiatan pengolahan ikan secara tradisional di Sumatera Utara sudah mampu memberikan nilai tambah pada pengelolaannya dan dapat menanggulangi kemerosotan harga akibat pembusukan ikan.

Menurut Budiharsono (2001), rendahnya pemanfaatan potensi sumberdaya kelautan yang sedemikian besar terutama disebabkan oleh: (1) pemerintah dan masyarakat masih mengutamakan eksploitasi daratan; (2) teknologi eksploitasi dan eksplorasi lautan memerlukan tingkat teknologi yang tinggi; (3) kualitas sumberdaya manusia yang terlibat dalam sektor kelautan relatif masih rendah, khususnya di perikanan tangkap; (4) introduksi teknologi baru dalam perikanan tangkap, tidak terjangkau oleh nelayan yang kondisi sosial ekonominya rendah; dan (5) sistem kelembagaan yang ada belum mendukung pada pengembangan sektor kelautan.

Adapun tujuan dari kegiatan pengabdian pada masyarakat ini adalah: 
1. Masyarakat terutama kaum perempuan mampu melakukan diversifikasi usaha melalui pembuatan usaha bakso ikan dan tekwan ikan yang memiliki nilai ekonomis tinggi.

2. Masyarakat menjadi lebih memahami jika hasil tangkapan ikan mampu di olah menjadi berbagai produk.

3. Dari kegiatan penyuluhan ini kaum perempuan mampu meningkatkan pendapatan keluarga dengan melakukan usaha di rumah.

Manfaat dari kegiatan pengabdian pada masyarakat ini adalah:

a. Memotivasi masyarakat Kelurahan Pasar Bengkulu terutama kaum perempuan untuk dapat membantu perekonomian keluarga dalam meningkatkan atau menambah pendapatan keluarga yang mampu menambah tingkat kesejahteraan keluarga

b. Bagi pemateri kegiatan penyuluhan ini bermanfaat dalam pelaksanaan unsur tri dharma perguruan tinggi.

c. Terjalinnya komunikasi ilmiah antara Unib dengan masyarakat Kelurahan Pasar Bengkulu.

\section{METODE PENGABDIAN}

\section{Mitra Kegiatan}

Masyarakat yang menjadi mitra dan sasaran dalam kegiatan penyuluhan ini adalah kaum perempuan atau ibu rumah tangga yang dapat berpartisipasi dalam membantu perekonomian keluarga melalui usaha pengolahan hasil tangkapan nelayan. Ibu rumah tangga dapat memnfaatkan waktu luang yang dimiliki dengan melakukan usaha-usaha ekonomis seperti pengolahan produk berbasis ikan laut. Sasaran utama dari penyuluhan ini adalah 25 orang ibu rumah tangga yang diharapkan kedepannya ke 25 ibu rumah tangga ini mampu menularkan pengetahuannya kepada kaum perempuan sekelilingnya.

\section{Bahan dan Alat}

Dalam kegiatan pelatihan pembuatan produk berbasis ikan laut ini, peralatan dan bahan yang di pakai masih sederhana sehingga setiap rumah tangga dimungkinkan untuk membuat/praktek sendiri di rumah. Bahan utama yang dipakai adalah produk yang banyak dijumpai di Kelurahan Pasar Bengkulu yakni ikan laut. Hal ini dikarenakan Kelurahan Pasar Bengkulu terletak di pesisir pantai Bengkulu.

\section{Metode Pelaksanaan Kegiatan}

Sesuai dengan tujuan yang telah dikemukakan maka metode kegiatan pengabdian masyarakat yang akan dilakukan adalah:

a) Metode diskusi dan tanya jawab yang dilaksanakan saat penyampaian materi pelatihan.

b) Metode demonstrasi pembuatan bakso dan tekwan ikan laut. 
Kegiatan pengabdian pada masyarakat ini dilaksanakan di ruang aula kantor Kelurahan Pasar Bengkulu Kota Bengkulu. Penyuluhan dilaksanakan pada tanggal 12 Juli 2012. Kegiatan dimulai dengan penyusunan proposal, persiapan pelaksanaan kegiatan, menghubungi khalayak sasaran, pelaksanaan penyuluhan dan pelatihan, pengurusan surat keterangan, penyelesaian laporan dan melaksanakan evaluasi kegiatan.

Penentuan waktu pelaksanaan disesuaikan dengan kesesuaian waktu luang antara peserta dan tim pengabdi dimana pada waktu tersebut tim pengabdi belum mulai kuliah, sehingga kegiatan bisa terkonsentrasi. Peserta kegiatan pelatihan adalah ibu-ibu rumah tangga kelurahan Pasar Bengkulu yang berjumlah yang semula direncanakan sebanyak 20 orang akan tetapi pada saat pelaksanaan peserta yang mengikuti sebanyak 25 orang.

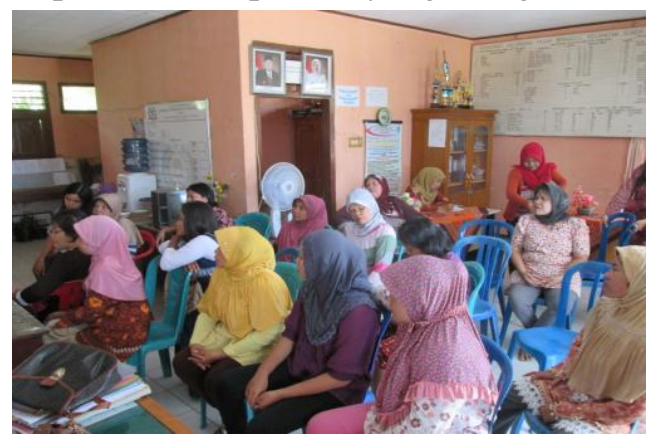

Gambar 1. Peserta Pelatihan

Dari kegiatan yang dilaksanakan dapat diketahui bahwa peserta antusias untuk mengikuti kegiatan baik pada penyampaian materi maupun praktek, hal ini terlihat dari banyaknya pertanyaan peserta dan diskusi yang berlangsung antara peserta dan narasumber. Dari diskusi yang berlangsung diketahui bahwa kegiatan ini sangat bermanfaat dimana ibu-ibu rumah tangga di kelurahan Pasar Bengkulu mempunyai alternatif lain pengolahan ikan laut selain dibuat ikan asin.

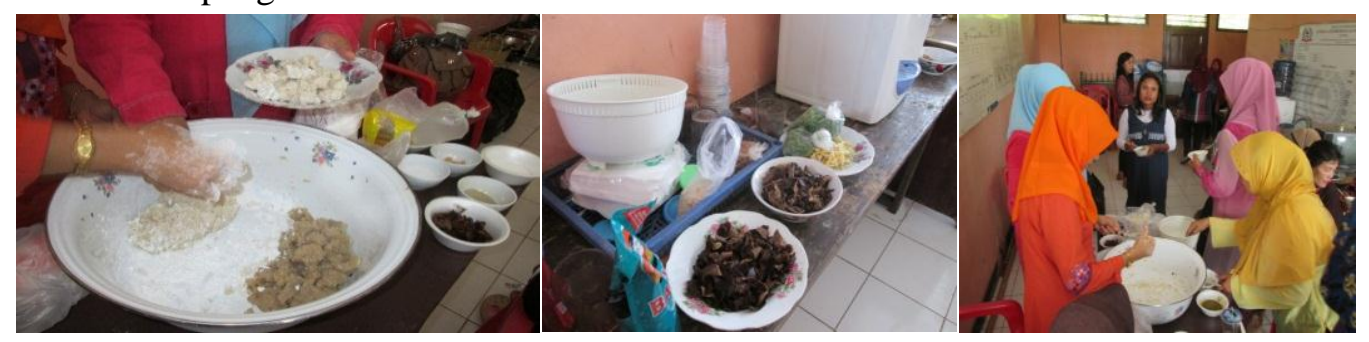

Gambar 2. Praktek Pembuatan Tekwan Ikan Laut 

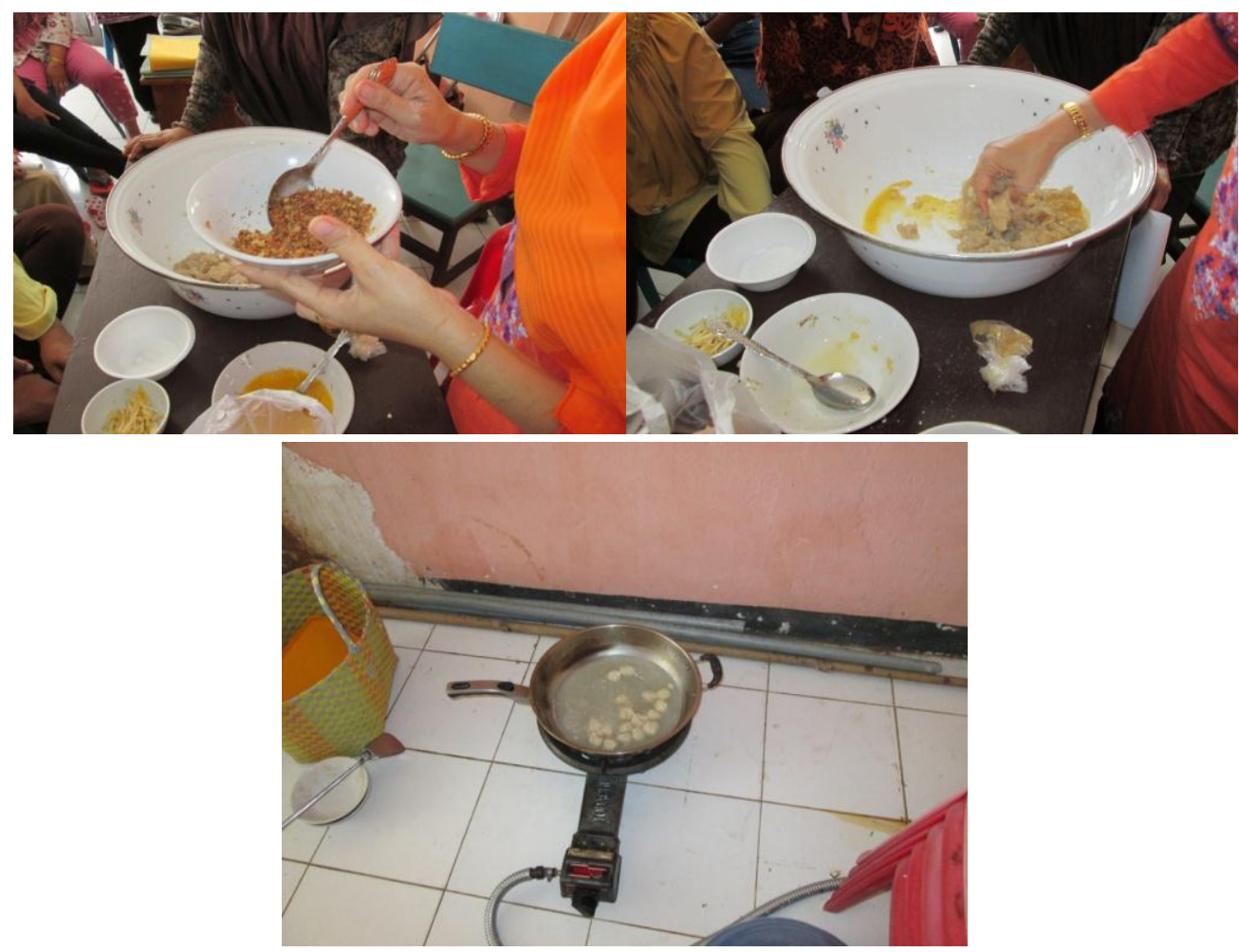

Gambar 3. Praktek Pembuatan Bakso Ikan

Keberhasilan dari kegiatan pengabdian pada masyarakat ini tidak terlepas dari beberapa faktor yang mendukung kegiatan ini sendiri. Adapun faktor pendukung keberhasilan kegiatan ini adalah:

1. Khalayak sasaran dalam kegiatan pengabdian yang dilakukan menyambut baik kegiatan ini. Hal ini terlihat dari meningkatnya jumlah peserta yang semula direncanakan berjumlah 20 orang dan pada saat pelatihan dilaksanakan bertambah menjadi 25 orang. Hal yang mendorong ibu-ibu rumah tangga mengikuti kegiatan ini dikarenakan mereka memperoleh pengetahuan dan keterampilan baru sebagai upaya diversifikasi produk olahan ikan laut.

2. Para ibu rumah tangga mempunyai pilihan kegiatan peningkatan ekonomi keluarga dengan diversifikasi produk olahan ikan laut sekaligus sebagai upaya pemanfaatan waktu luang para ibu rumah tangga di Kelurahan Pasar Bengkulu.

3. Kegiatan pengabdian kepada masyarakat ini mendapatkan dukungan penuh dari aparat kelurahan dan tim penggerak PKK kelurahan Pasar Bengkulu yang memfasilitasi tempat dilaksanakannya praktek saat penyuluhan/pelatihan.

Meskipun kegiatan pengabdian kepada masyarakat ini dapat dikatakan cukup berhasil, namun terdapat beberapa kendala dan kelemahan dalam kegiatan ini antara lain adalah masih ada anggapan dari masyarakat jika ada kegiatan/program yang dilakukan di kantor kelurahan maka akan ada kucuran dana. Padahal hakikatnya kegiatan ini dimaksudkan untuk peningkatan kreatifitas warga terutama ibu rumah tangga untuk 
menambah penghasilan keluarga, atau paling minimal mampu mengolah produk bergizi untuk keluarga.

\section{KESIMPULAN DAN SARAN}

\section{Kesimpulan}

Berdasarkan pada hasil dan pembahasan di atas maka dapat disimpulkan bahwa:

1. Kegiatan pengabdian kepada masyarakat dengan melaukan pelatihan praktek pengolahan produk basis ikan laut dapat dilaksanakan dengan baik dan lancar dengan jumlah peserta sebanyak 25 orang ibu rumah tangga.

2. Metode yang digunakan dalam pelatihan ini adalah metode ceramah, dan latihan/praktek pembuatan bakso ikan dan tekwan ikan laut.

3. Berdasarkan hasil pelatihan ibu-ibu rumah tangga yang menjadi peserta pelatihan mampu mengembangkan produk ikan laut menjadi makanan olahan ikan laut yakni bakso dan tekwan ikan laut.

\section{Saran}

Adapun Saran yang dapat dilakukan antara lain:

1. Program atau kegiatan pengabdian ini dapat dilanjutkan melihat tingginya antutiasme ibu rumah tangga yang mau mengikuti kegiatan praktek ini.

2. Ada pendampingan kepada kelompok-kelompok kerja di keluarahan pasar bengkulu sehingga hasil kegiatan pembuatan bakso ikan dapat terus dilakukan.

\section{DAFTAR PUSTAKA}

Budiharsono S., 2001, Teknik Analisis Pembangunan Wilayah Pesisir dan Lautan, Pradnya Paramita, Jakarta.

Dyckman, Thomas R., Roland E. Dukes, Charles J. Davis, 2000, Akuntansi Intermediate, Edisi Ketiga, Jilid 1, Erlangga, Jakarta.

Erizal, Jamal, 1991, Pusat Penelitian Agro Ekonomi, Bogor, http://repository.usu.ac.id/bitstream/123456789/30213/4/Chapter\%2 0II.pdf

Harahap, Sofyan Syafri, 2002, Teori Akuntansi, Edisi Delapan, PT. Raja Grasindo Persada, Jakarta.

Monografi Kelurahan Pasar Bengkulu, 2014, Bengkulu. 
Wild, John J., K. R. Subramanyam, dan Robert F. Hasley, 2005, Financial Statement Analysis, Alih Bahasa Yanivi S. Bachtiar dan S. Nurwahyu Harahap, Analisis Laporan Keuangan, Edisi 8, Buku I, Salemba 4, Jakarta. 